5. Прохорова, О.Г. Основы психологии семьи и семейного консультирования. Учебное пособие для вузов / О.Г. Прохорова. - М.: Юрайт, 2018. - 821 с.

6. Шнейдер Л. Б. Психология семейных отношений. Курс лекций. — М.: Апрель-Пресс, Изд-во ЭКСМО-Пресс, 2000. - 512 с.

7. Харлова, О. Н. Семейные отношения и их влияние на формирование личности ребенка / О. Н. Харлова. - Текст : непосредственный // Актуальные вопросы современной педагогики : материалы VIII Междунар. науч. конф. (г. Самара, март 2016 г.). — Самара : ООО "Издательство АСГАРД", 2016.

\title{
Канунников Р.И. \\ Эмоциональный аспект патриотического воспитания обучающихся в образовательных организациях МВД России
}

Уральский юридический институт МВД России (Россия, Екатеринбург)

doi: $10.18411 / l j-02-2021-185$

idsp: ljournal-02-2021-185

\section{Аннотация}

Отличительной чертой современного воспитания является формирование патриотической позиции у подрастающего поколения, потребности в духовнонравственном совершенствовании, в уважении к историко-культурному наследию своего народа и всех народов России.

В процессе патриотического воспитанияобучающихся образовательных организаций МВД России эмоциональный аспект имеет огромное значение так как, выступает в виде подкрепления иактивизации новых нравственных знаний о морали и праве, усваиваемых в образовательной среде.

Ключевые слова: патриотическое воспитание, эмоции, эмоциональный аспект.

\section{Abstract}

A distinctive feature of modern education is the formation of a patriotic position in the younger generation, the need for spiritual and moral improvement, in respect for the historical and cultural heritage of their people and all peoples of Russia. In the process of patriotic education of educational organizations of the Ministry of Internal Affairs of Russia, the emotional aspect is of great importance, since it acts as a reinforcement and activation of new moral knowledge about morality and law, assimilated in the educational environment.

Keywords: Patriotic education, emotions, emotional aspect.

Воспитание в современном российском обществе реализуется в условиях постоянных экономических и политических изменений, в ходе которых постоянно меняется социокультурная жизнь подрастающих поколений, а также принципы функционирования образовательных учреждений. В образовательных учреждениях одним из приоритетных направлений является патриотическое воспитание обучающихся.

В процессе высшего образования учебного, все структурные компоненты этого образования ведут к внутренним изменениям личности: образованности, воспитанности, интеллектуального, нравственного, эмоционального развития, повышению профессионализма, то есть к формированию внутренней культуры будущего специалиста.

Существует множество определений патриотизма, но наиболее значимым на наш взгляд является понятие часто определяемое, что патриотизм - это качество личности.

В словаре под редакцией В.С. Безруковой «патриотизм - это положительное духовно-нравственное качество личности, выражающееся как любовь к Родине, своему 
народу, местам своего рождения и проживания». Патриотизм складывается на основе национального сознания, общей культуры и идентичности.

По мнению С.К. Рощина формирование патриотических чувств основывается на национальном самосознании. Носители национального самосознания должны признают право народов на проявление уникальности, не навязывая при этом свои нормы и ценности. Самосознание уникальности и составляет основу патриотических чувств. Все это является особенно важным, так как курсанты, как правило, учатся в многонациональной среде. Поэтому при выборе героев для подражания и их личностных качеств необходимо учитывать национальный фактор [4].

Формирование культуры патриотизма осуществляется в процессе обучения и воспитания. Целенаправленно воздействуя в ходе реализации этих процессов на сознание и чувства курсантов, происходит формирование у них определенныхустановок, мотивов, понятий, принципов ценностей, идеалов. Все это является основой в дальнейшем формирования черт характера,поведения, специфики межличностного общения.

Поступая в образовательные организации МВД России, обучающиеся имеют определенный набор различных качеств. Задача педагогов состоит в формировании патриотизма с опорой на эмоциональность. Эмоциональное подкрепление в этом случае выступает в виде способа формирования патриотических чувств: чувство долга перед Родиной, интернационализма, чувство чести. Вместе с тем необходимо помнить и о том, что в некоторых случаях под влиянием таких эмоциональных чувств развивается пафосный патриотизм, который характеризуется внешним энтузиазмом. [1].

Эмоциональный аспект включает в себя подкрепления и переживания усвоения нравственно - патриотических норм и понятийобучающимися. Установку на усвоение этих понятий формирует педагог, опираясь как правило, на своей жизненный опыт. В результате у курсантов к концу первого курса чаще всего уже сформированы основы мировоззрения и нравственные устои, эстетические вкусы и идеалы. Но путь становления личности, формирования всех ее качеств еще не завершен.

Систематическая работа по развитию патриотизма у обучающихся должна основываться, прежде всего на формировании эмоционально - нравственного отражении той действительности, в которой они находятся. Педагогу при этом необходимо определить дальнейший потенциал нравственного развития обучающихся.

Как считает Е.П. Ильин, эмпатия сближает людей, обогащает процесс их взаимодействия сопереживанием [3]. Эмпатические межличностные взаимоотношения между курсантами должны основываться на чувстве тождественности с другими, взаимной межличностной идентификации, что в свою очередь позволит глубже осознать и принять нравственные идеалы. Особенную важность это приобретает в формировании патриотизма в межкультурной коммуникации обучающихся с опорой на эмоциональную составляющею усвоения патриотических качеств на основе нравственных образов. Эмоциональный компонент патриотизма способствует формированию таких нравственных качеств, таких как гуманизм, альтруизм, любовь к родине, отвага.

В процессе воспитания и обучения происходит выработка патриотического мировоззрения, основанная на появлении личностного смысла, подкрепленного соответствующим эмоциональным фоном и эмоциональными переживаниями.

Специфика содержания патриотической работы должна характеризоваться преобладанием эмоционального аспекта над информативным. В содержании такой работы определяющее значение имеет практическая сторона знаний. Как отмечает И. Я. Лернер, эмоциональная сторона усвоения ценностных понятий проявляется не только в отношении к приобретению знаний, но и «к их передаче, к их использованию» $[5]$. 
Решающие значение имеет создание педагогических ситуаций на занятиях, которые включали бы в себя элементы дискуссий, основанные в том числе и на эмоциях курсантов. В результате чего должна происходить борьба мнений, отстаивание обучающимися своих суждений, в результате чего у них начинает складываться своя внутренняя позиция.

Любая система всегда нуждается в инновациях. Инновации в системе патриотического воспитания должны включать в себя поиск новых форм, методов, создания принципиально новых концепций воспитания обучающихся в образовательных организациях МВД России с учетом целенаправленной государственной политики в этом вопросе. Подкрепляться инновационная стратегия должна с учетом эмоционального аспекта.[2].

Итоговая цель такой инновационной стратегии состоит в осознании ценности выбранной профессии, необходимости и значимости профессиональной деятельности для общества в целом. В данном случае она заключается в уважительном отношении к служебной деятельности офицера. На основе уважительного отношения к своей деятельности необходимо продолжать формирование патриотических чувств.

Привлечение курсантов к нравственной оценке тех или иных событий, поступков исторических деятелей, литературных героев представляет собой своеобразный вид социальной практики, которую можно и нужно организовывать на занятиях.

Знакомясь с произведениями на патриотическую тему, наблюдая за поступками героев, учащиеся получают огромный эмоциональный заряд. Обогащение духовного мира учащегося в процессе литературного чтения происходит через постижение идеалов и через сопереживание, сочувствие и соучастие. Ярко воспринятые образы, пережитые картины оказывают влияние на духовный мир. Художественная литература целенаправленно стимулирует эмоциональную и мыслительную деятельность.

Изучение художественных произведений на патриотическую тему содержит необходимый эмоциональный заряд, заставляет курсантов переживать прочитанное, осознавать не только информационную, но и духовную ценность изучаемого материала, что в свою очередь оказывает разностороннее и глубокое влияние на их нравственное развитие. Обращение к таким произведениям дает возможность вывести учащихся на серьезные размышления о человеческих ценностях.

Эмоции являются тем самым ключом, позволяющим познать самое существенное во внутреннем мире человека. Лишь сформированная внутренняя убежденность позволяет в дальнейшем проявлять нравственно - патриотические качества в жизни общества и профессиональной деятельности. Описание подвига, смелости, героизма, мужества, преданности, источником которых является патриотизм, оказывает воздействие на эмоциональное состояние обучающихся в образовательных организациях МВД России.

Эмоциональные состояния зависят от зрелости и устойчивости знаний в вопросе патриотизма, связанные прежде всего, с ценностными ориентациями обучающихся в образовательных организациях МВД России.

Ценностные ориентации обучающихся являются составляющей патриотического воспитания ипроявляются через личное отношение к ним во всех сферах общественных отношений. Но им также необходимо постоянное эмоциональное подкрепление.

Патриотическое воспитание в процессе обучения и воспитания, требует формирования социально направленного, личностного отношения обучающихся в образовательных организациях МВД России к нормам морали и права, проявления патриотических чувств. Реализация данной задачи возможно лишь в условиях последовательной и целенаправленной работы по формированию системы идейных 
взглядов и убеждений, с использованием эмоционально окрашенной деятельности обучающихся.

$* * *$

1. Вилюнас В.К. Психология эмоций. - Спб.: Изд-во Питер, 2006. - 496 с.

2. Гладких В.В. Гражданско-патриотическое воспитание молодежи в поликультурной среде вуза: системно - деятельностный подход: автореф. дисс. доктора. пед. наук: 13.00.05 / В. В. Гладких. Тамбов, 2011.- 50 с.

3. Ильин Е.П. Эмоции и чувства.- Спб.: Изд-во Питер, 2001. - 752 с.

4. Кольцова В.А. Социально-психологические проблемы патриотизма и особенности его воспитания в современном российском обществе / В.А. Кольцова, В.А. Соснин // Психологический журнал. 2011. - Т. 26. - № 4. - С. 89-97.

5. Лернер И.Я. Развивающее обучение с дидактических позиций. М. //Педагогика.-1996.-№2 С. 7 11.

\section{Капитонова Л.В. \\ Обзор современных российских исследований, посвященных рефлексии и рефлексивности}

Приамурский государственный университет имени Шолом-Алейхема (Россия, Биробиджан) doi: $10.18411 / l j-02-2021-186$

idsp: ljournal-02-2021-186

\section{Аннотация}

В настоящем обзоре литературы систематизировано 45 научных работ, посвященных рефлексии и рефлексивности, опубликованных с 2006 г. и по настоящее время. Дано определение терминов, показано, что большая часть современных публикаций затрагивает сферу рефлексии и рефлексивности, связанную с проблемами обучающихся и личностными аспектами названных феноменов.

Ключевые слова: рефлексивность, рефлексия, психология, сознание, психическое состояние, личность.

\section{Abstract}

This literature review systematizes 45 scientific papers on reflection and reflexivity, published from 2006 to the present. The definition of the terms is given, it is shown that most of the modern publications concern the sphere of reflection and reflexivity, associated with the problems of students and the personal aspects of these phenomena.

Keywords: reflexivity, reflection, psychology, consciousness, mental state, personality.

Термин «рефлексивность», берет начала от слова «рефлексия», что означает обращение назад, смотрение в себя или на себя. В современном написании термин был помещен в философский словарь немецким мыслителем Платоном Рудольфом Гоклениусом в 1613 г. (Савчук, 2012). В философском аспекте рефлексия способность к отражению, в психологическом - к критическому самоанализу. Элементарная рефлексия, а их выделяют несколько видов, присуща всем людям. Практически все, хоть иногда, задумывались над причинами различных моментов своей жизни и деятельности, над тем, почему и как мы делаем что-либо. Механизм саморефлексии может распространяться и на внешний мир: различают рефлексию по поводу различных сторон и проявлений жизни, природы и человечества в целом; и как ее высшую форму - философскую рефлексию (Энциклопедический словарь, 2004). В другом аспекте рефлексия, это свойство нашего мышления, и в более широком смысле, сознания. С этой стороны, рефлексия есть познание, изучение, обмысливание чего- 